\title{
MJN ORAL CARE AND ITS ASSOCIATION WITH SOCIO-DEMOGRAPHIC CHARACTERISTICS IN LEUKEMIC PATIENTS RECEIVING CHEMOTHERAPY
}

\author{
Salwa Hagag Abdelaziz \\ Medical Surgical Nursing, Faculty of Nursing, Cairo University, Egypt \\ CorrespondingAuthor's Email:nadakimo2005@yahoo.com/shagag2005@cu.edu.eg
}

\begin{abstract}
The aim of the current study was to assess knowledge and practice of oral care in leukemic patients receiving chemotherapy. Also determine whether sociodemographic characteristics are associated with patients' knowledge and practice of oral care. A descriptive cross-sectional design was used. A convenience sample of 150 patients attending National Cancer Institute in Cairo was recruited according to inclusion criteria. Data was collected using demographic sheet, structured questionnaires related to patient's knowledge and practice of oral care. The mean age of the study sample was $(40.67 \pm 11.76)$. Most patients $(81.30 \%)$ did not use medicated mouth wash for oral care while receiving chemotherapy and (63.33\%) had no idea about correct technique of teeth brushing. Lower percentage (36.00\%) of the patients have knowledge about oral problems while $89.30 \%$ did not have knowledge about suitable time for dental checkup. Thus, it was concluded that most of the patients had inadequate knowledge and practice of oral care. There was association between age, level of education and occupation in relation to practice of oral care. Patients' occupation was associated with their knowledge of oral care. There was no association between place of residence and family income in relation to knowledge and practice of oral care. Establishing communication between multidisciplinary team including dentists, nurses and oncologists is needed to enhance patients' knowledge and practice of oral care. Continuous monitoring of practicing oral care among patients is recommended during the process of chemotherapy administration. It is recommended to replicate the study in different setting.
\end{abstract}

Keywords: Oral care, Leukemia, Chemotherapy

\section{INTRODUCTION}

Leukemia is cancer of the body's blood-forming tissues, including the bone marrow and the lymphatic system (Pai, Ongole \& Banerjee, 2019). Many types of leukemia among adults were explained widely in literature review. In order to treat leukemia, chemotherapy is administered and widely spread in the blood stream to reach cancer cells (Poulopoulos, Papadopoulos \& Andreadis, 2017). It affects the normal cells of the body causing many side effects such as bleeding and oral complications (Rahnama et al., 2015). There is clear evidence that oral mucositis $(\mathrm{OM})$ is considered the most common side effects of chemotherapy and affect up to $100 \%$ of patients (Radha \& Ojha, 2014). OM is characterized by infiltration of the inflammatory cells followed by epithelial disruption and ulceration. It increases during the first week after the administration of a high dose of chemotherapy and declines 2-4 weeks after the treatment is completed (Nape-as et al., 2007). This leads oncology nurses to develop standardized guidelines for health care providers to be applied in nursing practice. The guidelines should include essential part related to patients' education about knowledge and practice of oral care before, during and after receiving chemotherapy. Studies have shown that unpracticed oral health care during the chemotherapy treatment increases the risk of inability to eat, drink, swallow and speak which may lead to longer hospital stay (Chaveli - Lopez, 2014). Socio demographic characteristics should be considered during the chemotherapy treatment.

Patients' socio-demographic characteristics such age, educational level, family income, malnutrition and poor oral health increase the risk of OM. Also taste disturbances are widely detected in patients undergoing chemotherapy and cause discomfort. As a result, patients may refuse the intake of food which may delay the patient's recovery (Imai et al., 2013). Most common taste changes include a metallic taste, loss of taste 
acuity, or bitterness when the starting administration of chemotherapy (Ravasco, 2005).

Many studies recommended several agents in the management and prevention of OM and these could be successful if handled by nursing staff and multidisciplinary team. As nurses spend most of their time with patients during the stages of diseases and its treatment, oral hygiene protocols recommend dental intervention before chemotherapy, which included the use of dental floss and oral rinses. In cases of infection and OM saline solution and nystatin are effective and recommended for patients (McCaul, 2012; Imai et al., 2013). So, the researcher of the current study suggests that nurses should collaborate with the dentist and oncologist in organizing the treatment plan before the initiation of chemotherapy and continue till the end of recovery. As most of cancer patients experience distress and discomfort during treatment period. The oral problems are the major source of discomfort which requires nurse's contribution in spreading awareness about importance of oral care. To best of the researcher knowledge still now there are no studies conducted on oral care of leukemia patients receiving chemotherapy in Egypt. Therefore, the aim of the current study is to assess patients' knowledge and practice of oral care. Also the study will determine whether oral care is associated with patients' sociodemographic characteristics.

\section{Research Questions}

1: Are demographic characteristics associated with oral care in leukemic patients receiving chemotherapy?

2: Are leukemic patients receiving chemotherapy have sufficient knowledge of oral care?

3: Are leukemic patients receiving chemotherapy practice oral care?

\section{METHODOLOGY}

\section{Research Design}

A cross-sectional descriptive design was utilized to conduct the study. This type of design provides the researcher with numerous information at once such as patients sociodemographic characteristics in relation to knowledge and practice of oral care (Wood \& Haber, 2015).

\section{Setting}

The study was conducted in inpatients clinic at National Cancer Institute in Cairo, Egypt from August
2018 to December 2019.

\section{Sample}

A convenient sample consisted of 150 leukemic patients receiving chemotherapy. The study sample was calculated using of Power analysis of $95(\beta=1-0.95$ $=0.5$ ) at $\alpha 0.05$ (one-sided) with large effect size $(0.5)$ was used as the significance level9.

\section{Inclusion criteria:}

- Patients on second cycle of chemotherapy

- Both genders

- Above 18 years

\section{Exclusion criteria:}

- Patients receiving radiotherapy

- Chronic disease such as heart failure and diabetes mellitus.

\section{Tools}

\section{Data was collected using the following tools:}

(a) Structured Questionnaire: It includes patients' socio-demographic characteristics such as age, gender, level of education, occupation, income and place of residence.

(b) The second part has data related to patients' knowledge about oral problems and its complication such as malnutrition and dry mouth. Also, this part assesses patients' knowledge about using soft toothbrush and dental checkup before starting chemotherapy.

(c) In this part data were collected related to patient practice of oral care such as: using soft brush to clean mouth, cleaning mouth for two minutes, using disinfectant, eating soft diet, inspecting oral cavity, change brush every month and using right techniques for cleaning mouth.

(d) In this part were data collected regarding patient practice on preventive measures of oral problems such as complete oral health exam, eating balanced diet, use of medication and proper oral care.

The questionnaires related to Knowledge and practice of oral care developed from Radha \& Ojha, (2014). and modified by the researcher of the current study. The content validity of the questionnaires was established by panel of expertise in the field of oncology and nursing. The questionnaires were then translated 
into Arabic language and reviewed by language expert to ensure simplicity of language.

\section{Procedure}

Once official permission was obtained to conduct the current study, the patients were interviewed individually to explain the nature and purpose of the study. Informed and written consent was obtained for all patients to protect their ethical rights. The interview was conducted for 45 minutes approximately. The researcher emphasized to the patients that their participation is entirely voluntary. Once interview was completed all patients were provided with a pamphlet technique of oral care and benefits of practicing it. The study was conducted in three phases; Initial, planning and implementation.

\section{Initial phase}

It this phase the researcher were searching the literature review using scientific data base. Also, assessment of the hospital environment and ensuring the availability of the study sample, ensuring cooperation and support from nursing staff. In-addition, the researcher was specifying and writing study methodology to conduct the study.

\section{Planning phase}

Based on the previous phase the pilot study was conducted to ensure clarity and validity of the study tools. Final tools were developed by the researcher.

\section{Implementation phase}

At the beginning of this phase, the researcher ensures to explain nature and purpose of the study to the patients who met the inclusion criteria. The patients recruited for the study were interviewed for 30 minutes to fill in the structured questionnaire related to demographic data as well as knowledge and practice of oral care. Once the interview was closed the researcher provided the patients with instructions regarding oral care procedure, benefits of follow-up and signs of oral complications that may develop during chemotherapy and method of dealing with them. The instruction on oral care were done for 15 minutes.

\section{Data Analysis}

Statistical package for the social science (SPSS) program, version 20 was used for data analysis. The socio-demographic variables such as age, education level, occupation and family income were analyzed using descriptive statistics (frequency and percentage). Association between patients' knowledge and practice of oral care and selected socio-demographic variables was assessed by independent $t$ test and one-way ANOVA test. Association of knowledge and practice of oral health care with patients' age was assessed by Pearson correlation ( $r$-test). Also, association of total knowledge and total practice of oral care were assessed with $r$-test. Level of significance was adopted at $P<0.05$.

\section{RESULTS}

Table 1: Frequency and Percentage Distribution of Patients' Demographic Characteristics (No=150)

\begin{tabular}{|c|c|c|}
\hline Demographic variables & No & $\%$ \\
\hline \multicolumn{3}{|l|}{ Age } \\
\hline $18<25$ year & 17 & 11.30 \\
\hline $25<35$ year & 34 & 22.70 \\
\hline $35<45$ year & 53 & 35.30 \\
\hline $45<55$ year & 27 & 18.00 \\
\hline $55<65$ year & 17 & 11.30 \\
\hline $65<75$ year & 2 & 1.30 \\
\hline $\operatorname{Mean} \pm$ SD & \multicolumn{2}{|c|}{$40.67 \pm 11.76$} \\
\hline \multicolumn{3}{|l|}{ Education } \\
\hline Primary & 42 & 28.00 \\
\hline Preparatory & 25 & 16.70 \\
\hline Secondary & 32 & 21.30 \\
\hline University & 32 & 21.30 \\
\hline Can't read and write & 19 & 12.70 \\
\hline \multicolumn{3}{|l|}{ Place of Residence } \\
\hline Rural & 81 & 54 \\
\hline Urban & 69 & 46 \\
\hline \multicolumn{3}{|l|}{ Occupation } \\
\hline Unemployed & 50 & 33.33 \\
\hline Employed & 100 & 66.67 \\
\hline \multicolumn{3}{|l|}{ Income } \\
\hline Adequate & 92 & 61.33 \\
\hline Inadequate & 58 & 38.67 \\
\hline
\end{tabular}


As demonstrated in table 1 the mean age $(40.67 \pm 11.76)$ of the patients recruited under the study and most of them $(66.67 \%)$ were employed. As regards to the educational level $(28.00 \%$ and $21.30 \%)$ of studied patients have primary and university degree respectively. The same table revealed that nearly half of patients were from rural (54\%) and had adequate income (61.33\%).

Table 2: Frequency and Percentage Distribution of Patients' Practice of Oral Care (NO.=150)

\begin{tabular}{|c|c|c|c|}
\hline Variables & Categories & No & $\%$ \\
\hline \multirow{2}{*}{$\begin{array}{l}\text { Using teeth brush every } \\
\text { day }\end{array}$} & Yes & 75 & 50.00 \\
\hline & $\begin{array}{l}\text { No } \\
\text { Causes } \\
\text { - low Income } \\
\text { - lack of awareness } \\
\text { - fear of gum bleeding }\end{array}$ & $\begin{array}{l}75 \\
22 \\
38 \\
15\end{array}$ & $\begin{array}{l}50.00 \\
14.67 \\
25.33 \\
10.00\end{array}$ \\
\hline \multirow{2}{*}{$\begin{array}{l}\text { Using soft brush for } \\
\text { teeth cleaning }\end{array}$} & Yes & 49 & 32.67 \\
\hline & $\begin{array}{l}\text { No } \\
\text { Causes } \\
\text { - don't use brush } \\
\text { - lack of awareness }\end{array}$ & $\begin{array}{l}75 \\
26 \\
\end{array}$ & $\begin{array}{l}50.00 \\
17.33\end{array}$ \\
\hline \multirow{2}{*}{$\begin{array}{l}\text { Brush teeth for more } \\
\text { than two minutes }\end{array}$} & Yes & 64 & 42.67 \\
\hline & $\begin{array}{l}\text { No } \\
\text { Causes } \\
\text { - don't use brush } \\
\text { - lack of awareness }\end{array}$ & $\begin{array}{l}76 \\
10\end{array}$ & $\begin{array}{l}50.66 \\
6.67\end{array}$ \\
\hline \multirow[b]{2}{*}{$\begin{array}{l}\text { Clean mouth while } \\
\text { brushing teeth }\end{array}$} & Yes & 75 & 50.00 \\
\hline & $\begin{array}{l}\text { No } \\
\text { Causes } \\
\text { - don't use brush }\end{array}$ & 75 & 50.00 \\
\hline \multirow[b]{2}{*}{$\begin{array}{l}\text { Using medicated mouth } \\
\text { wash for oral care }\end{array}$} & No & 122 & 81.33 \\
\hline & $\begin{array}{l}\text { Yes } \\
\text { Type of solution } \\
\text { - Tantam } \\
\text { - Nystatine }\end{array}$ & $\begin{array}{l}16 \\
12\end{array}$ & $\begin{array}{l}10.67 \\
8.00\end{array}$ \\
\hline \multirow{2}{*}{$\begin{array}{l}\text { Take soft diet during } \\
\text { chemotherapy treatment }\end{array}$} & Yes & 116 & 77.33 \\
\hline & $\begin{array}{l}\text { No } \\
\text { Causes } \\
\text {-lack of awareness }\end{array}$ & 34 & 22.67 \\
\hline \multirow[b]{2}{*}{$\begin{array}{l}\text { Changing teeth brush } \\
\text { every month }\end{array}$} & Yes & 58 & 38.67 \\
\hline & $\begin{array}{l}\text { No } \\
\text { Causes } \\
\text { - don't use brush } \\
\text { - low income }\end{array}$ & $\begin{array}{l}75 \\
17 \\
\end{array}$ & $\begin{array}{l}50.00 \\
11.33 \\
\end{array}$ \\
\hline \multirow{2}{*}{$\begin{array}{l}\text { Performing correct } \\
\text { technique of brushing } \\
\text { teeth }\end{array}$} & Yes & 55 & 36.67 \\
\hline & \begin{tabular}{l}
\multicolumn{1}{c}{ No } \\
Causes \\
- don't use brush \\
- lack of awareness
\end{tabular} & $\begin{array}{l}71 \\
24\end{array}$ & $\begin{array}{l}47.33 \\
16.00\end{array}$ \\
\hline \multirow[b]{2}{*}{$\begin{array}{l}\text { Inspection of oral cavity } \\
\text { once a day }\end{array}$} & Yes & 93 & 62.00 \\
\hline & $\begin{array}{l}\text { No } \\
\text { Causes } \\
\text { - lack of awareness } \\
\text { - forget to do }\end{array}$ & $\begin{array}{l}47 \\
10\end{array}$ & $\begin{array}{l}31.33 \\
6.67\end{array}$ \\
\hline
\end{tabular}

Table 2 illustrated that $50 \%$ of the studied patients did not use toothbrush daily due to low income, lack of awareness and fear of gum bleeding $(14.67 \%, 25.33 \%$ and $10.00 \%$ ) respectively. The same table revealed that most patients $(81.33 \%)$ did not use medicated mouth wash for oral care during receiving chemotherapy. In relation to questions related to type of $\operatorname{diet}(22.67 \%)$ of the studied patients showed that they lack awareness about eating soft diet during chemotherapy treatment. With reference to performing correct techniques of brushing teeth $(63.67 \%)$ of the studied patients had no idea about it. The same table showed that $62 \%$ of patients under the study inspect their oral cavity once a day.

Table 3: Association of Demographic Characteristics and Patients' Practice of Oral Care (No. $=150)$

\begin{tabular}{|c|c|c|c|c|c|}
\hline Variables & Categories & Mean & SD & $\begin{array}{l}\text { Test } \\
\text { result }\end{array}$ & $\begin{array}{l}P \\
\text { value }\end{array}$ \\
\hline \multirow{5}{*}{ Education } & Primary & 12.571 & 1.927 & \multirow{5}{*}{$17.89 * *$} & \multirow{5}{*}{$0.00 *$} \\
\hline & Preparatory & 12.880 & 2.774 & & \\
\hline & Secondary & 14.437 & 2.213 & & \\
\hline & University & 15.281 & 1.224 & & \\
\hline & $\begin{array}{l}\text { Can't read and } \\
\text { write }\end{array}$ & 11.263 & 0.806 & & \\
\hline \multirow{2}{*}{$\begin{array}{l}\text { Place of } \\
\text { Residence }\end{array}$} & rural & 12.271 & 2.001 & \multirow[t]{2}{*}{$7.79 *$} & \multirow[t]{2}{*}{0.29} \\
\hline & urban & 14.797 & 1.952 & & \\
\hline \multirow{2}{*}{ Occupation } & Employed & 15.160 & 1.299 & \multirow{2}{*}{$8.87 *$} & \multirow{2}{*}{$0.00 *$} \\
\hline & Unemployed & 12.570 & 2.271 & & \\
\hline \multirow{2}{*}{ Income } & Adequate & 13.989 & 2.176 & \multirow{2}{*}{$3.83^{*}$} & \multirow{2}{*}{0.86} \\
\hline & Inadequate & 12.551 & 2.341 & & \\
\hline
\end{tabular}

$* P \leq 0.05 ; *$ Means independent $t-$ test; **means one-way ANOVA test

Table 3 revealed that there was highly statistically significant association between patients practice of oral care and educational level as well as occupation $(P=$ $0.000)$ 
Table 4: Frequency and Percentage Distribution of Patients' Knowledge of Oral Care $($ NO. $=150)$

\begin{tabular}{|c|c|c|c|}
\hline Variables & Categories & No & $\%$ \\
\hline $\begin{array}{l}\text { Having } \\
\text { knowledge about } \\
\text { oral problem }\end{array}$ & $\begin{array}{l}\text { No } \\
\text { Yes } \\
\text { - Decay } \\
\text { - Mucositis } \\
\text { - taste change } \\
\text { - chewing } \\
\text { - gum bleeding }\end{array}$ & $\begin{array}{l}69 \\
(81) \\
17 \\
39 \\
4 \\
13 \\
8\end{array}$ & $\begin{array}{l}46.00 \\
(54.00) \\
11.33 \\
26.00 \\
2.67 \\
8.67 \\
5.33\end{array}$ \\
\hline $\begin{array}{l}\text { Oral problem can } \\
\text { lead to } \\
\text { malnutrition }\end{array}$ & $\begin{array}{l}\text { No } \\
\text { Yes } \\
\text {-bad Hygiene } \\
\text {-Inflammation } \\
\text {-taste change } \\
\text {-difficult chewing }\end{array}$ & $\begin{array}{l}92 \\
(58) \\
12 \\
4 \\
12 \\
30\end{array}$ & $\begin{array}{l}61.33 \\
(38.67) \\
8.00 \\
2.67 \\
8.00 \\
20.00\end{array}$ \\
\hline $\begin{array}{l}\text { Preventive } \\
\text { measures should } \\
\text { begin before the } \\
\text { treatment }\end{array}$ & $\begin{array}{l}\text { No } \\
\text { Yes }\end{array}$ & $\begin{array}{l}135 \\
15\end{array}$ & $\begin{array}{l}90.00 \\
10.00\end{array}$ \\
\hline $\begin{array}{l}\text { Smoking leads to } \\
\text { oral problem }\end{array}$ & $\begin{array}{l}\text { No } \\
\text { Yes } \\
\text {-change color } \\
\text {-tooth decay } \\
\text {-change odor }\end{array}$ & $\begin{array}{l}77 \\
\\
31 \\
31 \\
11\end{array}$ & $\begin{array}{l}51.33 \\
20.67 \\
20.67 \\
7.33\end{array}$ \\
\hline $\begin{array}{l}\text { Dental check-up } \\
\text { should be done at } \\
\text { least two weeks } \\
\text { before starting } \\
\text { chemotherapy }\end{array}$ & $\begin{array}{l}\text { No } \\
\text { Yes }\end{array}$ & $\begin{array}{l}134 \\
16\end{array}$ & $\begin{array}{l}89.33 \\
10.67\end{array}$ \\
\hline $\begin{array}{l}\text { Toothbrush can } \\
\text { prevent oral } \\
\text { problems }\end{array}$ & $\begin{array}{l}\text { No } \\
\text { Yes }\end{array}$ & $\begin{array}{l}81 \\
69\end{array}$ & $\begin{array}{l}54.00 \\
46.00\end{array}$ \\
\hline $\begin{array}{l}\text { Frequent sips of } \\
\text { water should be } \\
\text { taken for dry } \\
\text { mouth }\end{array}$ & $\begin{array}{l}\text { No } \\
\text { Yes }\end{array}$ & $\begin{array}{l}86 \\
64\end{array}$ & $\begin{array}{l}57.33 \\
42.67\end{array}$ \\
\hline
\end{tabular}

Table 4 showed that $(54.00 \%)$ of the patients have knowledge about oral problems and among those $26 \%$ having knowledge and were aware that chemotherapy treatment can lead to mucositis and the minority $(5.33 \%)$ stated that chemotherapy can lead to gum bleeding. The same table illustrated that $46 \%$ of the studied patients did not have knowledge about oral problems. The majority of the studied patients $(89.33 \%)$ did not have knowledge about suitable time for dental checkup that should be done two weeks before chemotherapy treatment. In relation to receiving frequent sips of water for dry mouth; around half $(57.33 \%)$ of the studies patients did not have idea about this information.
Table 5: Association Of Demographic Characteristics And Patients' Knowledge Of Oral Care (No.=150)

\begin{tabular}{|c|c|c|c|c|c|}
\hline Variables & Categories & Mean & SD & $\begin{array}{l}\text { Test } \\
\text { result }\end{array}$ & $\begin{array}{c}P \\
\text { value }\end{array}$ \\
\hline \multirow{5}{*}{ Education } & Primary & 16.500 & 2.35 & \multirow{5}{*}{$1.61 * *$} & \multirow{5}{*}{0.174} \\
\hline & Preparatory & 17.280 & 2.07 & & \\
\hline & Secondary & 16.343 & 1.79 & & \\
\hline & University & 17.187 & 1.38 & & \\
\hline & $\begin{array}{l}\text { Can't read and } \\
\text { write }\end{array}$ & 17.211 & 1.72 & & \\
\hline \multirow{2}{*}{$\begin{array}{l}\text { Place of } \\
\text { Residence }\end{array}$} & rural & 16.901 & 2.13 & \multirow{2}{*}{$0.46^{*}$} & \multirow{2}{*}{0.07} \\
\hline & urban & 16.753 & 1.72 & & \\
\hline \multirow{2}{*}{ Occupation } & Unemployed & 16.580 & 1.46 & \multirow[b]{2}{*}{$1.28 *$} & \multirow[b]{2}{*}{$0.001 *$} \\
\hline & Employed & 16.960 & 2.15 & & \\
\hline \multirow{3}{*}{ Income } & Adequate & 16.869 & 1.89 & \multirow{3}{*}{$0.29 *$} & \multirow{3}{*}{0.25} \\
\hline & & & & & \\
\hline & Inadequate & 16.775 & 2.04 & & \\
\hline
\end{tabular}

Significant at $* P \leq 0.05 ; *$ Means independent t test; **means one-way ANOVA test

Table 5 revealed that with reference to association between demographic characteristics and patients' knowledge of oral care, there was statistically significant association between patient's occupation and their knowledge about oral care $(P<0.05)$.

Table 6: Association of Knowledge and Practice of Oral Care with Patients' Age (NO.=150)

\begin{tabular}{|l|c|c|}
\hline \multirow{2}{*}{ Pearson correlation } & \multicolumn{2}{|c|}{ Age } \\
\cline { 2 - 3 } & $R$-test & P Value \\
\hline Total Knowledge & $-0.117-$ & 0.154 \\
\hline Total Practice & $-0.424-$ & $0.000 *$ \\
\hline
\end{tabular}

Significant at $* P \leq 0.05$

Table 6 with reference to association between age and patients' knowledge of oral care, there was no statistically significant association $(P=0.154)$. While the practice of oral care, the researcher found highly statically significant association with patients age $(P$ $=0.000$ ). 


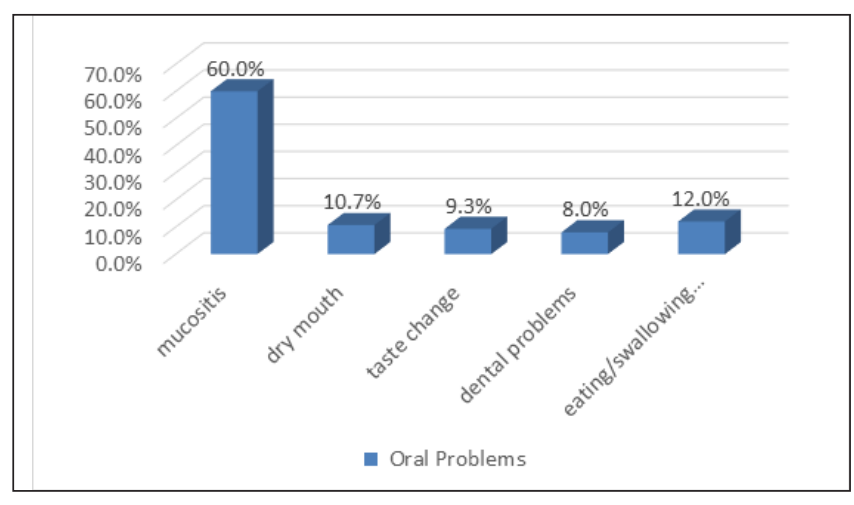

Figure 1: Current Patients Complain of Oral Problems

Figure 1 revealed that most of patients under the study $(60 \%)$ suffer from mucosities while the minority $(8.00 \%)$ having dental problems and $(12.00 \%)$ suffering from difficulty in eating and swallowing.

\section{DISCUSSION}

Regarding type of oral problem, the higher percentage $(54 \%)$ of the studied patients had knowledge about types of oral problems. This finding is consistent with the study conducted in North West England (Hoad, Grant \& Griffiths, 1987) which found that over half $(52.6 \%)$ of the study sample had adequate knowledge about oral care. In contrast another study conducted in Nepal and found that around one third of the study sample (28.4\%) had adequate knowledge about oral care (Radha \& Ojha, 2014).

As regards to having knowledge about mucositis as an oral problem, in the present study, 26\% responded that inflammation of mouth caused by chemotherapy. This finding is inconsistent with conducted by Radha \& Ojha, (2014) who found that higher percentage (90.2\%) of the study sample responded that mucositis was caused by chemotherapy. Gum bleeding was responded by $5.33 \%$ of the studied patients, whereas the minority $(2.67 \%)$ of the patients responded that taste change is considered as an oral problem. This is in the same line with the study conducted in Nepal (Radha \& Ojha, 2014).

In relation to the question of preventive measure should begin before treatment, $90 \%$ of the studied patients had no knowledge. The finding was incongruent with survey study conducted by Roberts, (2005) which reported that the higher percentage $(71 \%)$ of the studied sample had adequate knowledge about prevention and treatment of oral problems. In the current study, $10 \%$ of the studied patients reported that preventive measures should begin before the treatment and this finding is in the same line with the study conducted by Radha \& Ojha (2014). Also, among the studied patients, 38.67\% mentioned that oral problems can lead to malnutrition. Inaddition, $42.67 \%$ of patients had awareness that frequent sips of water should be taken for dry mouth. This finding is in the same line with the study conducted in Nepal by Radha \& Ojha, (2014).

In relation to practice oral care, the current study found that only $32.67 \%$ of patients used soft brush. This finding is consistent with the study conducted to assess nursing interventions and supportive care for the prevention and treatment of oral mucositis associated with cancer treatment which found $57.5 \%$ of patients under the study used soft brush (Eilers, 2004). In the current study, $60 \%$ of patients was suffering from oral mucositis. Among the patients used medicated mouth wash, $8 \%$ utilized Nystatine solution for oral care and $81.33 \%$ did not use any medicated solution. This finding indicated that the higher percentages of patients need sufficient health education for appropriate practice of oral care.

As regards to practice of eating soft diet during chemotherapy treatment, $77.33 \%$ of the studied patients responded that they are taking soft diet during the chemotherapy. In relation to question related to daily inspection of oral cavity, $62 \%$ responded that they inspect their oral cavity every day. The findings were congruent with a study conducted to evaluate mucositis prevention by improved dental care in acute leukemia patients (Djuric et al., 2006). In relation to performing correct techniques of brushing teeth, 36.67\% had right practice towards correct techniques of brushing teeth. This finding is similar to the study carried out in Korea (Stone \& Hood, 2007) and highlighted that $30 \%$ of the studied patients had the right practices of brushing teeth.

In relation to association of practice of oral health care and sociodemographic characteristics, the researcher found significant association as regards to age, level of education and occupation $(P<0.05)$. While the association between patients' knowledge and sociodemographic characteristics, it was seen there was with patients' occupation. The finding is like the study conducted by Rubenstein \& Perterson, (2008) which highlighted that there was no significant association of knowledge and 
age as well as educational level. In contrast, other study conducted by Radha \& Ojha, (2014) which reported that there was a significant association between knowledge of patients and age as well as level of education.

\section{CONCLUSION}

The authors of the current study concluded that patient's knowledge and practice of oral health care was inadequate to overcome oral problems. This could be enhanced by establishing communication channel between multidisciplinary team including dentists, nurses and oncologists. Continuous monitoring of practicing oral care is necessary during the process of chemotherapy administration. Age, level of education and occupation are associated with patients' practice of oral health care. Occupation was also associated with patients' knowledge of oral care. The study cannot be generalized to the whole population because the researcher used small sample size. Till date only few researches were carried out in the field of the current study. So, the researcher recommended replication of the study in different setting.

\section{Conflict of Interests}

The author declares that they have no conflict of interest.

\section{ACKNOWLEDGEMENT}

The author is thankful to the institutional authority for completion of the work.

\section{REFERENCES}

Chaveli-Lopez, B. (2014). Oral toxicity produced by chemotherapy: A systematic review. Journal of Clinical and Experimental Dentistry, 6, e81-90.

Djuric, M., Hillier-Kolarov, V., Belic, A. \& Jankovic, L. (2006). Mucositis prevention by improved dental care in acute leukemia patients. Supportive Care Cancer, 14(2), pp 137-146.

Eilers, J. (2004). Nursing interventions and supportive care for the prevention and treatment of oral mucositis associated with cancer treatment. Oncology Nursing Forum, 31(4), pp 13-23.

Hoad, G., Grant, A. \& Griffiths, C. (1987). The dental health of an elderly population in North-west England: Results of a survey undertaken in the Halton Health Authority. Journal of Dentistry, 15(4), pp139-146.

Imai, H., Soeda, H., Komine, K., Otsuka, K. \& Shibata, H. (2013). Preliminary estimation of the prevalence of chemotherapy-induced dysgeusia in Japanese patients with cancer. BMC Palliative Care, 12:38.

McCaul, L. (2012). Oral and dental management for head and neck cancer patients treated by chemotherapy and radiotherapy. Dental Update, 39(2), pp 135-140.

Nape-as, J.J., Brennan, M.T., Bahrani-Mougeot, F.K., Fox, P. \& Lockhart, P.B. (2007). Relationship between mucositis and changes in oral microflora during cancer chemotherapy. Oral Surgery, Oral Medicine, Oral Pathology and Oral Radiology, 103(1), pp 48-59.

Pai, R., Ongole, R. \& Banerjee, S. (2019). Oral care in cancer nursing: Practice and barriers. Indian Journal of Dental Research, 30(2), pp226-230.

Poulopoulos, A., Papadopoulos, P. \& Andreadis, D. (2017). Chemotherapy: oral side effects and dental interventions, A review of the literature. Stomatological Disease and Science, 1(2), pp 35-49.

Radha, A. \& Ojha, Na. (2014). Knowledge and Practice on Oral Care among the Patients Receiving Chemotherapy. American Journal of Cancer Prevention, 2(1), pp 9-13.

Rahnama, M., Madej-Czerwonka, B., Jastrzębska-Jamrogiewicz, I. \& Jamrogiewicz, R. (2015). Analysis of the influence of parenteral cancer chemotherapy on the health condition of oral mucosa. Contemporary Oncology,19(1), pp 77-82. 
Ravasco, P. (2005). Aspects of taste and compliance in patients with cancer. European Journal of Oncology Nursing, 9 (Suppl 2), S84-91.

Roberts, J. (2005). Developing an oral assessment and intervention tool for older people. British Journal of Nursing, 6(1), pp 28-32.

Rubenstein, E. \& Perterson, S. (2008). Clinical practice guidelines for the prevention and treatment of cancer therapyinduced oral and gastrointestinal mucositis. Supplement to Cancer, 100(9), pp 2026-2033.

Stone, J \& Hood, H. (2007). Interventions for preventing oral mucositis for patients with cancer receiving treatment (Cochrane Review). The Cochrane Library, Issue 4, Chichester, UK: John Wiley \& Sons.

Wood, L. \& Haber, J. (2015). Nursing research methods and critical appraisal for evidence-based practice.8th edition. Elsevier, China, pp183-190. 